\title{
Nursing Care for Elderly People in Germany and China: A Bilateral Comparison and Exploration of Policy Transfer
}

Tao Liu*

Department of Sociology at Bielefeld University, Germany

${ }^{*}$ Corresponding author: Dr. Tao Liu, Lecturer, Bielefeld University, Bielefeld, Germany, Tel: 0049-521-1063975; E-mail: tao.liu@uni-bielefeld.de

Received date: August30, 2014; Accepted date: September 26, 2014; Published date: September 29, 2014

Copyright: ( 2014 Liu T, et al. This is an open-access article distributed under the terms of the Creative Commons Attribution License, which permits unrestricted use, distribution, and reproduction in any medium, provided the original author and source are credited.

\begin{abstract}
This article is dedicated to outlining two nursing care models for elderly people in Germany and China. Shaped by the European welfare state model, Germany has launched a statutory long-term care insurance program aimed at integrating multiple actors, such as the family, intermediary organizations, non-profit organizations and private providers into a supply structure within a mandatory social care insurance system, where the welfare state acts as lawmaker and regulator for public nursing care. Compared to the German system, China has a rudimentary nursing care system characterized by a hybrid model, which relies on both conventional family care and individual private insurance. After introducing elderly care in both countries, this review article explores the possibility of transferring the German model of long-term care insurance to China to reduce the increasing problem of elderly care. The soaring demand for elderly care and underdeveloped public services for nursing care represent a great challenge for contemporary Chinese society.
\end{abstract}

Keywords: Nursing care; Welfare state; Long-term care insurance; Hybrid model; Policy transfer

\section{Introduction}

Over the last few decades, the aging population has increasingly become a serious global problem. Not only industrialized nations but also transition economies have undergone drastic demographic transitions. During this process, the issue of elderly care has been the focus of discussion for many OECD countries. Currently, this issue has crossed the border of OECD nations and become a matter of increasing concern for transition economies. Faced with the continuing acceleration of demographic aging, how are developed countries and emerging economies able to tackle the problem of care for the elderly with disabilities?

This academic article focuses on elderly care in two nations Germany and China, both of which have encountered similar demographic and social challenges. In Germany, one of the most important industrial nations, the Total Fertility Rate (TFR) has decreased from 2.0 in 1970 to 1.40 in 2011, while life expectancy has increased from 69.3 years in 1960 to 80.7 years in 2011. As the largest transition economy, China has also experienced a dramatic decline in birth rate and a steady increase in life expectancy. Its TFR has decreased from 5.5 in 1970 to 1.60 in 2011, while life expectancy has increased by more than 30 years between 1960 and 2011 (from 43.5 years to 75.0 years) [1]. Until 2010, persons aged 60 and over in Germany comprise 26.3 percent of the whole population [2]; in China, there are 177 million persons aged 60 and over, representing 13.26 percent of the entire population [3]. Both countries are encountering the increasing problem of population aging and elderly care.

These two countries have been selected for comparison because both have institutional similarities in the domain of social policy. Germany is the first nation in the world that had created comprehensive social insurance systems in the era of Bismarck, such as old age insurance, health insurance and industrial injury insurance. Historically, East Asian nations like Japan and China have consistently shown a strong desire and keen interest to learn from the social insurance systems of the Prussian and the unified German Empire, This historical legacy of bilateral linkage affects the contemporary development of social protection in East Asia. For instance, China has sought to adopt the occupational injury insurance system of Germany since $2005[1,2]$. In the field of health insurance, China has also approached the Bismarck model of social insurance, introducing an urban health insurance system and new rural cooperative medical system since 1990s. Unlike the British Beveridge model, the social insurance system, like the health care system in China and Germany, is funded through insurance contributions, not through payroll taxes. Thanks to the long-standing social and cultural affinity between Western Europe and East Asia, it is logical to raise the question if contemporary China can learn from the German nursing care model to create a brand new long-term care insurance system.

\section{A Bilateral Comparison of the Nursing Care Models of Germany and China}

Nursing care in Germany has been associated with an ideal type of the continental welfare state model, which bears comprehensive responsibility for the social well-being of all citizens [3-5]. Originally, those in need of care applied for assistance from the health insurance system and general household assistance program. However, the soaring expenditure for the care-dependent citizens proved to be a severe burden on both the health insurance system and the household assistance program. Constant investment into elderly care via the traditional social security system has exacerbated the stress on the system's financial condition [6]. In 1990s, heated debate about whether long-term care should be separated from other social security programs resulted in legislative change enacted by the German parliament in 1994, which came into force one year later. This change represented a landmark development in the history of the German 
welfare state. A century after the birth of the modern social insurance system, the Statutory Long-term Care Insurance system (SLCI) was created and included in the general social insurance program [7].

The SLCI has a few features in common with other systems, but it also has its own distinctive aspects. As prescribed by the Social Security Code XI (SSC XI) [8], all individuals insured by the health insurance system are also enrolled in long-term care insurance. Because the insurance is mandatory, the majority of the German population is covered by this new program. Financing of the SLCI is based on the conventional "principle of parity" in the German welfare state, which means that employees and employers share the payment of insurance premiums. This payment amounted to 1.7 percent of basic income at its inception and now, after an incremental increase in contributions, it amounts to 2.05 percent of income. Like the health insurance system, the SLCI is a system with a high degree of distribution and inclusiveness because almost all employees must pay insurance contributions for the SLCI regardless of their class of risk. People who fall into the highest risk categories and who need urgent care, such as the elderly and the chronically ill, do not need to pay any additional premiums. By organizing the system in this way, a distribution effect between high- and low-risk people has occurred [11]. The organizer of SLCI, the Nursing Care Insurance Fund (NCIF), cannot prevent high-risk people from joining. The principle of inclusion ensures that all German residents have equal access and equal entitlement to the SLCI (ibid).

The SLCI in Germany has distinctive features that make it different from other types of social insurance. First, people in need of care are differentiated into three different levels, according to which different allowances and benefits in kind are delivered. Care level I is designated for the substantially needy, care level II for the severely needy and care level III for those with the most serious care needs. The definition of the different degrees of care is stipulated by the health services of the health insurance companies, and assignment to one of the care levels determines which benefits those who are in need can claim. At each of these three nursing care levels, individuals can decide if they wish to claim monetary care benefits or care services (benefits-in-kind). In the home care category, most beneficiaries prefer to claim monetary payment - care allowances - for their family members. For example, people diagnosed with needs at care level I can claim a 235 Euro care allowance or 450 Euro care benefits in kind. Those beneficiaries in need of stationary care usually have no other choice than to claim care services rather than money (Table 1). In the neediest cases, for those at care level III, 1,918 Euro can be paid out as a reimbursement for care services.

\begin{tabular}{|l|l|l|l|}
\hline & Care level I & $\begin{array}{l}\text { Care Level } \\
\text { II }\end{array}$ & Care Level III \\
\hline Home care & & & \\
\hline $\begin{array}{l}\text { Care allowances } \\
\text { Benefit in kind }\end{array}$ & 235 & 440 & $\begin{array}{l}700 \\
1550 \text { (in case of hardship up to } \\
1918)\end{array}$ \\
\hline Stationary care & 1023 & 1100 & $\begin{array}{l}1550 \text { (in case of hardship up to } \\
1918)\end{array}$ \\
\hline
\end{tabular}

Table 1: Cash transfer and benefits in kind for long-term care insurance according to benefit level (in Euros) in the year 2014 in Germany.
The SLCI program was never intended to assume full responsibility for those in need of care; rather, it encourages the care services and activities of families, households, civil society actors and intermediary non-profit organizations to fulfill the task of long-term care.The welfare state regulates the long-term care sector through lawmaking, benchmarking, monitoring and evaluation [11]. The most decisive institutional arrangement of the SLCI is that the nursing care activities undertaken by family members and relatives are also financed by the NCIF; the contributions of family members who give up their work for the purpose of providing nursing care at home are recognized as social work and monetarily compensated. The role and function of non-state actors are not attenuated; rather, the state sticks to a principle of "subsidiarity," which means that only if the family and society cannot provide sufficient assistance will the welfare state intervene in this process [10].

Unlike the health insurance system, the target of the SLCI in Germany is not complete coverage of the needs of those dependent on care. For example, persons needing care usually pay the costs of accommodation and catering themselves if they select a care service in nursing homes. Even care allowances and care benefits-in-kind can only partially cover the costs of those dependent on care; they must pay all other costs out of their own pocket. While the health insurance system is designed to cover the full medical needs of patients, the SLCI only reimburses partial costs for those in need. According to statistics, nearly half of the cost of long-term care has been covered by the SLCI, and those dependent on care must pay the other half by themselves [12].

Compared to the German model of the welfare state and mandatory long-term care insurance, the Chinese model of nursing care is overwhelmingly shaped by the traditional Confucian care model. The care of elderly people is mainly left to family members and relatives. Scholars differentiate various types of family care: (1) In elderly married couples, the wife cares for the husband.(2) Adult children care for their parents. Conventionally the adult daughter is the caregiver but in some cases, the daughter-in-law takes over the responsibility of caring for parents and in households with more family members, the children share the task of providing care. (3) In a hybrid care-model, the elderly wife and adult children share the care activities. (4) The relatives of extended families undertake care activities. (5) In very few cases, neighbors and friends undertake the task of care. (6) Beyond care provided by families, various organizations such as retirement homes, sheltered housing for older people, day care centers and nursing homes provide professional and semi-professional care for people who require it. In rare cases, wealthy communities in some cities subsidize day care centers, which provide care services at a level far below market prices. In most cases, nursing homes are privatized and offer care services only according to market prices [13-15].

In essence, there is not yet a public model of long-term nursing care for the elderly in China. Comprehensive care service supplied through a public nursing service model or mandatory long-term care insurance has not been established. In contemporary China, a hybrid model of family care and commodified private nursing care has instead been created. Elderly people without offspring and with a low pension income are not cared for sufficiently. The highly commodified model of private nursing care leads inexorably to the exclusion of impoverished disabled people. 


\section{The Present Situation of Nursing Care for Elderly People in Germany and China}

The latest statistics from the Federal Statistical Office in Germany (FSOG) regarding nursing care in 2013 showed that in 2011 nearly 2.5 million people in Germany are in need of care. Of this population, 1.76 million are cared for at home, which amounts to nearly 70 percent of the total. Nearly 743,000 persons receive nursing care in nursing homes, which makes up 30 percent of all cases. This outcome shows that even today most people needing care prefer care at home. Among home care cases, nearly 1.18 million are cared for through family members and relatives and they obtain care allowances. Some 576,000 persons have selected combined benefits, which means that they receive care services from family members and obtain mobile ambulant care services as well [16].Compared to data from 1999, the number of the persons in nursing homes has risen by 32.0 percent. The number of people in need of ambulatory care has expanded by 38.8 percent since 1999 and the recipients of the care allowance have risen by 15 percent in this period. Finally, the total number of people requiring long-term care has grown by 24.1 percent (ibid). The soaring increase in need for care services reflects the impact of demographic aging on the demand for care $[17,18]$.

According to gender- and age-related long-term care rates, the proportion of care-dependent people increases with age, but while the number of people needing care aged 60-65 is comparatively low (1.9 percent among men, 1.6 percent among women), the proportion of people needing care rises drastically among those aged 85-90 (28.6 percent among men, 41.9 percent among women) (Table 2).

\begin{tabular}{|l|l|l|l|}
\hline & Total & Male & Female \\
\hline Under $\mathbf{1 5}$ & 0.6 & 0.7 & 0.5 \\
\hline $\mathbf{1 5 - 6 0}$ & 0.5 & 0.6 & 0.5 \\
\hline $\mathbf{6 0 - 6 5}$ & 1.8 & 1.9 & 1.6 \\
\hline $\mathbf{6 5 - 7 0}$ & 2.8 & 3.0 & 2.7 \\
\hline $\mathbf{7 0 - 7 5}$ & 4.8 & 4.8 & 4.7 \\
\hline $\mathbf{7 5 - 8 0}$ & 9.8 & 8.9 & 10.5 \\
\hline $\mathbf{8 0 - 8 5}$ & 20.5 & 16.6 & 22.9 \\
\hline $\mathbf{8 5 - 9 0}$ & 38.0 & 28.6 & 41.9 \\
\hline $\mathbf{9 0}$ and older & 57.8 & 36.9 & 65.2 \\
\hline Total & 3.1 & 2.1 & 3.9 \\
\hline
\end{tabular}

Table 2: Long- term care rates according to gender and age in 2011 in Germany

Compared to the German system, the prospects for elderly care in China are dim. Traditionally, the idea prevailed that elderly people ought to be cared for by family members within the extended family system. But as a result of socio-economic modernization and urbanization, as well as a decline in family size and in the total fertility rate (the latter being particularly due to the adoption of a rigid onechild policy), the familiar and demographic basis for elderly care has been drastically eroded in China [19]. There are huge demands for care that have not yet been satisfied As of 2011, more than 33 million elderly people were in need of care and some 11 million of them required care beyond what the family could provide. However, only 2.1 million elderly people are cared for in nursing homes. In 2050, more than 87.8 million elderly people in China will need long-term care [20]. Nationwide, there are only 100,000 nursing staff qualified to provide professional care and this small number of nursing staff cannot satisfy the massive requirements for care in the Chinese market. The enormous gap between the demand for care and the precarious public infrastructure that is supposed to provide it has led to higher suicide rates among elderly people in Chinese society [19].

\section{Further discussion: a model transfer between Germany and China?}

This international comparative study is aimed at exploring the possibility of knowledge diffusion and the transfer of models between countries. Can Germany and China learn from each other through two very different models of nursing care? The answer is a clear affirmative. China has already the largest elderly population in the world and by 2050 , the number of people aged 65 and older will have increased by 2.5 times from 2010. With this dramatic rise, the number of elderly people in China will exceed the total number of elderly people in all OECD countries [21,22]. Over the same period, the number of all elderly people needing care will also grow 2.5 times. As it faces one of the largest demands for social care in the world, China cannot leave meeting the burden of care to traditional actors such as family, kinship and social networks alone. Considering that the onechild family is already the dominant type of household in contemporary Chinese society and more and more families remain childless, care through the family has been consistently weakened over the course of the country's great socio-economic transformation. When the parents of the one-child family reach retirement age and need care, the family will not be able to fulfill the requirements for care as they have done in the past. On the one hand, the conventional model of dependency upon the family and kinship networks is already anachronistic. On the other hand, the shift of responsibility and the involvement of market mechanisms are much more problematic than the family care model. Private care insurance schemes and private nursing homes rely overwhelmingly on the economic capacity and the classes of risk of claimants, which means that most people with marginal incomes and high care demands are excluded from this care market. Ironically, individuals who have the greatest need for care cannot receive assistance from a highly commodified private care insurance system.

Compared to family care and a private nursing care model, a social care insurance system is a potential solution to the issue of elderly care in China in the future. The core idea is not the shift of all tasks to a paternalistic state. Rather, the welfare state promotes a comprehensive care-model, combining the resources of families, neighbors, communities and professional nursing homes under the framework of state assistance, steering and regulation. By launching a nationwide mandatory social care insurance model, all employees would be obliged to participate in this novel social insurance scheme. Considering that more than 770 million individuals in China are employed in the labor market, if the long-term care insurance contributions of all employees were collected to finance the current demand for elderly care in Chinese society, the needs of the 33 million people needing care would be significantly more satisfied. There are several reasons that support the proposal of model transfer of the German long-term care insurance to China. First of all, China, as an emerging economy, has enjoyed rapid economic growth with a 
continuous increase in state revenues; thus, the central state has more fiscal capacity to undertake redistribution effectively. Secondly, due to the rapid industrialization and urbanization of the last three decades, the employment rate in China is comparatively high, and the unemployment rate remains low. In 2010, some 69.9 percent of women aged 16-59 years are employed in China. Since the financing of a long-term care insurance program is closely linked to the employment market and to paid insurance premiums, a high employment rate implies a solid monetary basis for the financial sustainability of the long-term care insurance program. Last but not at least, some Asian countries like Japan have followed the example of Germany and introduced a program of insurance for long-term care in their own countries aimed at coping with problems of a super-aging society [23]. China could benefit greatly from adopting the German model of social care insurance and heeding the latest experiences of its Asian neighbor countries.

\section{References}

1. Liu $\mathrm{T}$ (2010) Globale Wissensdiffusion und nationale Adaption im Bereich der wohlfahrtsstaatlichen Entwicklung: Eine Fallstudie zur Entwicklung der Arbeitsunfallversicherung in der VR China. Dissertation, Universität Bielefeld

2. Leisering L and Liu T (2010) "Globale Wissensdiffusion in der Sozialpolitik. Die Einführung der Arbeitsunfallversicherung in China”. Zeitschrift für Sozialreform 55: 175-206.

3. Esping-Andersen G (1990) The three worlds of welfare capitalism. Cambridge: Polity Press

4. Kaufmann FX (1997) Herausforderung des Sozialstaates. Frankfurt am Main: Suhrkamp

5. Kaufmann FX (2003) Varianten des Wohlfahrtsstaats: Der deutsche Sozialstaat im internationalen Vergleich. Frankfurt am Main: Suhrkamp

6. Stöbener AP (1996) Die Pflegeversicherung: ein Lehrstück über Aushandlungsprozesse eines „sozialen Problems“ in der Sozialpolitik. Konstanz: Hartung-Gorre

7. Krüger J (1997) Die Pflegeversicherung: ein neuer Typus der Sozialversicherung? Bielefeld Universität, Diplomarbeit
8. Klie T, Bachem J (2014) Sozialgesetzbuch XI: soziale Pflegeversicherung, Lehr- und Praxiskommentar. Baden-Baden: Nomos

9. Saltman RB, Dubois HFW, Chawla M (2006) The impact of ageing on long-term care in Europe and some potential policy responses. International Journal of Health Services 36: 719-746

10. Ullrich CG. (2005) Soziologie des Wohlfahrtsstaates. Frankfurt am Main/New York: Campus Verlag

11. Bäcker B, Bispinck R, Hofemann K, Naegele G (2000) Sozialpolitik und soziale Lage in Deutschland, Band II. Wiesbaden: Westdeutscher Verlag

12. Bäcker B, Bispinck R, Hofemann K, Naegele G (2010) Sozialpolitik und soziale Lage in Deutschland, Band II. Wiesbaden: Verlag für Sozialwissenschaften

13. Zhang XQ, Li DB (2011) Sociology of ageing in China. Beijing: Social Sciences Academic Press

14. Wu CP, Du P (2012) Ageing society and harmonious society. Beijing: China Population Publishing House

15. Chen T (2009) Sociology of ageing, Beijing: China Society Publishing House

16. Federal Statistical Office in Germany (2013)Pflegestatistik 2011. Wiesbaden: Statistisches Bundesamt

17. Häcker J, Hackmann T, Raffelhüschen B (2011) Soziale Pflegeversicherung heute und morgen: mit nachhaltigen Reformen aus der Krise. Köln: Deutsches Institut für Altersvorsorge

18. Popp M (2011) Die Pflegeversicherung: Stand, Probleme und Prognose. Hamburg: Kovac

19. Liu T, Flöthmann EJ (2013) The new ageing society: demographic transition and its effects on old-age insurance and care of the elderly in China. Zeitschrift für Gerontologie und Geriatrie 46 (5): 465-475

20. China Research Center on Ageing (CRCA) (2013) Research into disabled people in urban and rural areas in China. Beijing, Report by CRCA

21. Wu H, Zhang R (editor) (2011) Gerontological social work. Beijing: Beijing University Press

22. Liu T, Sun L (2014) An apocalyptic vision of ageing in China: Old age care for the largest elderly population in China. Zeitschrift für Gerontologie und Geriatrie 47. DOI: 10.1007/s00391-014-0816-5

23. Kabayama M, Kamide $\mathrm{K}$ et al. (2014) The role of public health nurses in Japanese long-term care prevention projects in the community. Journal of Nursing and Care 3: 1-5 